\title{
PERAN PEMERINTAH DAERAH DALAM MEMBANGUN CITY BRANDING DI KOTA TANJUNGPINANG (STUDI KASUS KAMPUNG PELANGI)
}

\author{
ROLE OF THE LOCAL GOVERNMENT BUILDING A CITY BRANDING IN \\ TANJUNGPINANG CITY \\ (CASE STUDY OF RAINBOW VILLAGE)
}

\author{
Erfan Hartono, Dian Prima Safitri, Fitri Kurnianingsih \\ Fakultas Ilmu Sosial dan Ilmu Politik Universitas Maritim Raja Ali Haji \\ Erfan.cool32@gmail.com
}

\begin{abstract}
Abstrak
Penelitian ini berdasarkan dari sebuah fenomena dimana pada tahun 2018 dibangun sebuah Kampung Pelangi di Kota Tanjungpinang. Kampung Pelangi yang merupakan pilot projek pembangunan Kampung Wisata Baru di Kota Tanjungpinang, menjadi salah satu terobosan baru untuk mengubah image kampung kumuh menjadi kampung yang indah dan dikenal melalui City branding Kota Tanjungpinang yang bertajuk "Pesona Tanjungpinang". City branding merupakan strategi dari sebuah kota atau daerah untuk membuat positioning yang kuat sehingga kota dan daerah tersebut dikenal secara luas. Penelitian ini menggunakan pendekatan kualitatif deskriptif untuk mengetahui Peran Pemerintah Daerah dalam membangun City Branding di Kota Tanjungpinang terkait positioning kampung wisata baru yaitu Kampung Pelangi yang dianggap menjadi ikon terbaru di Kota Tanjungpinang. Penelitian ini menggunakan dua subjek yaitu Dinas Pariwisata dan Kebudayaan Kota Tanjungpinang dan Kelurahan Melayu Kota Piring yang terlibat dalam Penanganan Kampung Pelangi. Teknik pengumpulan data dilakukan dengan observasi, wawancara serta dokumentasi. Hasil penelitian menunjukan bahwa Peran Pemerintah Daerah yang dilakukan oleh Dinas Pariwisata dan Kebudayaan Kota Tanjungpinang dalam membangun City Branding di Kota Tanjungpinang melalui Kampung Pelangi, yaitu: 1) Survei Pemetaan (Mapping Survey), 2) Analisis Kompetitif (Competitive Analysis), 3) Cetak Biru (Blueprint), dan 4) Implementasi (Implementation) masih belum optimal. Pemerintah daerah perlu mendorong pencapaian tujuan pembangunan kepariwisataan dan harus bisa menyediakan infrastruktur dan kerangka regulasi yang dapat mendorong swasta dan masyarakat untuk ikut berpartisipasi aktif dalam pembangunan kepariwisataan berbasis kampung wisata.
\end{abstract}

Kata Kunci: Peran, Pemerintah Daerah, City branding

\begin{abstract}
This study is based on a phenomenon in which in 2018 built a Rainbow Village in Tanjungpinang City. Rainbow Village which is a pilot project New Tourism Village development in Tanjungpinang, became one of the new ways to change the image of the slum
\end{abstract}


into a beautiful village and is known through, City branding Tanjungpinang, titled "Charm Tanjungpinang". City branding is a strategy of a city or region to make a strong positioning so that the city and region are widely known. This study used descriptive qualitative approach to determine the role of local government in building a city branding in Tanjungpinang related positioning its new tourist village of Rainbow Village which is considered to be the most iconic in Tanjungpinang. This study used two subjects, namely the Department of Tourism and Culture Tanjungpinang and Malay Village City Plates were involved in the handling of Rainbow Village. Data collected by interview and documentation. The results showed that the role of local governments conducted by the Department of Tourism and Culture in building city branding Tanjungpinang Tanjungpinang through Rainbow Village, namely: 1). Mapping Survey, 2). Competitive Analysis, 3). Blueprints and 4). Implementation,still not optimal. Local governments need to encourage the achievement of tourism development goals and must be able to provide infrastructure and regulatory frameworks that can encourage the private sector and the community to actively participate in tourism development based on tourist villages.

\section{Keywords: Role, Local Government, City branding}

\section{A. Pendahuluan}

Memasuki zaman yang serba digital, sekarang apa saja bisa menjadi objek untuk dibagikan pada banyak orang melalui media sosial. Salah satunya adalah Instagram sebagai platform berbagi foto, video, dan cerita. Oleh sebab itu, hal-hal yang Instagramable diprediksi menjadi tren 2019, termasuk soal travelling. Tanjungpinang sebagai Ibukota Provinsi Kepulauan Riau merupakan salah satu daerah tujuan wisata di Indonesia yang mempunyai objek-objek wisata yang cukup potensial untuk dikembangkan. Mengutip dari Visi kepariwisataan yang dicantumkan dalam Peraturan daerah Provinsi Kepulauan Riau Nomor 2 Tahun 2012 tentang Rencana Induk Pembangunan Pariwisata Provinsi (RIPPProv) Tahun 2012-2022 yang menyatakan "Terwujudnya Kepulauan Riau sebagai destinasi wisata yang berdaya saing tinggi di pasar
Nasional dan Internasional secara berkelanjutan serta mampu mendorong pembangunan daerah dan kesejahteraan masyarakat" kemudian diturunkan dalam bentuk 5 Misi nya yang salah satunya menyebutkan " Pengembangan pemasaran pariwisata yang sinergi, unggul, dan bertanggung jawab untuk meningkatkan kunjungan wisatawan nusantara dan mancanegara.

Salah satunya Kota Tanjungpinang yang membangun kawasan kampung wisata baru yaitu Kampung Pelangi. Kampung Pelangi merupakan kampung yang dicat warnawarni dengan lukisan 3 dimensi yang menghiasi setiap dinding rumah dan pagar tembok. Kampung Pelangi hadir menjadi jawaban baru bagi Kota Tanjungpinang untuk destinasi wisata yang intagramable, dimana tempatnya 
yang instagramable dan banyak spot foto yang sangat menarik untuk para wisatawan yang berkunjung. Diresmikan 10 Mei 2018 lalu oleh Penjabat Walikota Kota Tanjungpinang, Kampung Pelangi menjadi salah satu spot yang dibangun untuk merubah image kawasan di Kota Tanjungpinang, terutama kawasankawasan yang mulanya memiliki kesan kumuh untuk direkayasa menjadi satu spot yang menarik dan layak dijadikan sebagai salah satu destinasi wisata baru pariwisata.

Namun sangat disayangkan sejak diresmikan destinasi wisata kampung pelangi ini sangat minim perhatian dari pemerintah setempat. Dilihat dari masih kurangnya promosi serta kurangnya fasilitas sarana dan prasarana yang ada. Mulai dari kurangnya pengelolaan hingga banyak cat-cat yang sudah mulai memudar dan mengelupas. Berdasarkan latar belakang tersebut diatas, maka peneliti tertarik untuk melakukan penelitian dengan judul "Peran Pemerintah Daerah Dalam Membangun City brandingdi Kota Tanjungpinang (Studi Kampung Pelangi), dengan bertujuan untuk "Mengetahui dan Mendeskripsikan Peran Pemerintah Daerah dalam membangun City branding di Kota Tanjungpinang yaitu melalui Studi Kampung Pelangi,

Poerwodarminta (1995: 571)
"peran merupakan tindakan yang
dilakukan seseorang atau sekelompok
orang dalam suatu peristiwa".Berdasarkan
pendapat Poerwadarminta maksud dari
tindakan yang dilakukan seseorang atau

sekelompok orang dalam suatu peristiwa tersebut merupakan perangkat tingkah laku yang diharapkan, dimiliki oleh orang atau seseorang yang berkedudukan di masyarakat.Pitana dan Gayatri (2005:95), mengemukakan pemerintah daerah memiliki peran untuk mengembangkan potensi pariwisata daerahnya sebagai :

a. Motivator, dalam pengembangan pariwisata, peran pemerintah daerah sebagai motivator diperlukan agar geliat usaha pariwisata terus berjalan. Investor, masyarakat, serta pengusaha di bidang pariwisata merupakan sasaran utama yang perlu untuk terus diberikan motivasi agar perkembangan pariwisata dapat berjalan dengan baik.

b. Fasilitator, sebagai fasilitator pengembangan potensi pariwisata peran pemerintah adalah menyediakan segala fasilitas yang mendukung segala program yang diadakan oleh Dinas Pariwisata dan Kebudayaan. Adapun pada prakteknnya pemerintah bisa mengadakan kerja sama dengan berbagai pihak, baik itu swasta maupun masyarakat.

c. Dinamisator, dalam pilar good governance, agar dapat berlangsung pembangunan yang ideal, maka pemerintah, swasta dan masyarakat harus dapat bersinergi dengan baik. Pemerintah daerah sebagai salah satu stakeholder pembangunan pariwisata memiliki peran untuk mensinergiskan ketiga pihak tersebut, agar diantaranya tercipta suatu simbiosis mutualisme demi perkembangan pariwisata. 
Membangun City branding, City branding merupakan sebuah proses dari sebuah branding. Branding merupakan salah satu proses strategi yang sering diterjemahkan sebagai kegiatan beriklan. Namun, branding lebih merupakan aktivitas menentukan citra yang ingin dibentuk melalui berbagai macam kegiatan promosi (iklan, publisitas, dan sebagainya) seiring dengan penambahan fitur produk yang sesuai dengan citra yang ingin dibentuk. City branding adalah strategi yang membuat suatu tempat "berbicara" kepada masyarakat (yananda, rahmat dan salamah, 2014:34)

Dalam membangun sebuah city branding meliputi penentuan mapping survey, competitive analysis, blue print, dan implementation (Saputra, 2016:323). Peneliti akan membahas sedikit mengenai beberapa langkah diatas :

1. Mapping Survey; meliputi survey persepsi dan ekspektasi.

2. Competitive Analysis; melakukan analisis daya saing.

3. Blueprint; penyusunan cetak biru atau grand design daerah yang diinginkan, baik logo, semboyan, nick name, tagline.

4. Implementation; pelaksanaan grand design dalam berbagai bentuk media, seperti pembuatan media center, pembuatan events, iklan, dan lain sebagainya.

\section{B. Metode Penelitian}

Adapun pendekatan yang digunakan dalam penelitian ini adalah deskriptif dengan pendekatan kualitatif. Creswell (1998) menyatakan penelitian kualitatif sebagai suatu gambaran kompleks, meneliti kata-kata, laporan terinci dari pandangan responden, dan melakukan studi pada situasi yang alami. Lokasi penelitian ini adalah Dinas Pariwisata dan Kebudayaan Kota Tanjungpinang, kantor Lurah Melayu Kota Piring dan Kampung Pelangi dengan Jenis data dalam penelitian ini terdiri dari dua jenis, yaitu Data Primer dan Data Sekunder. Adapun informan yang diambil dalam penelitian ini yaitu Kepala Dinas Pariwisata dan Kebudayaan Kota Tanjungpinang, Kepala Bidang Destinasi dan Pemasaran Wisata Dinas Pariwisata dan Kebudayaan Kota Tanjungpinang, Kepala Bidang Ekonomi Kreatif Dinas Pariwisata dan Kebudayaan Kota Tanjungpinang, Lurah Melayu Kota Piring Tanjungpinang dan 1 orang anggota POKDARWIS Melayu Kota Piring, Ketua RT Kampung Pelangi, dan 1 orang Tokoh Masyarakat dan Pemuda Kampung Pelangi.

Teknik pengumpulan data dalam penelitian ini yaitu: Wawancara, Observasi, serta Dokumentasi. Sedangkan teknik analisis data peneliti menggunakan langkah-langkah seperti yang dikemukakan oleh Spradley (1980), dan Glaser dan Strauss (1967) yaitu: (1) Analisis Domain (Domain analysis), (2) Analisis Taksonomi (Taxonomy Analysis) , (3) Analisis Komponensial (Componential Analysis), dan (4) Analisis Tema Kultural (Discovering Cultural Themes).

\section{Pembahasan}

Untuk menjawab penelitian peneliti menggunakan dua jenis 
komunikasi yaitu; 1). Komunikasi sekunder terkait dengan aktivitas pemasaran kota yang disengaja dan terencana, 2). Komunikasi primer yang menitik beratkan pada potensi pengaruh atau peran dari tindakan yang dilakukan oleh Kota selaku Pemerintah Daerah (Local government) yang berkaitan dengan efek komunikasi dengan tindakan yang bersifat tidak sengaja. Peran pemerintah daerah dalam membangun city branding di Kota Tanjungpinang melalui studi Kampung Pelangi, peneliti menggunakan pendekatan teori Peran Pemerintah Daerah menurut pendapat Pitana dan Gayatri (2005:95) dan pendekatan teori membangun City branding menurut Saputra (2016:323). Menurut pendapat Pitana dan Gayatri, Pemerintah daerah memiliki peran untuk mengembangkan potensi pariwisata daerahnya dengan hasil perolehan data primer akan dibahas yang terdiri dari dimensi dan indikator-indikator dan akan dijelaskan satu persatu sebagai berikut:

\section{Pemerintah Daerah}

Menurut pendapat Pitana dan Gayatri Pemerintah daerah memiliki peran untuk mengembangkan potensi pariwisata daerahnya, yaitu:

a. Motivator, dalam pengembangan pariwisata motivator atau motivasi sangatlah penting, pemerintah daerah sebagai motivator diperlukan agar geliat usaha pariwisata terus berjalan. Investor, masyarakat, serta pengusaha dibidang pariwisata merupakan sasaran utama yang perlu untuk terus diberikan motivasi agar perkembangan pariwisata dapat berjalan dengan baik. Salah satu bentuk motivasi yang diberikan Dinas Pariwisata dan Kebudayaan Kota Tanjungpinang kepada masyarakat di Kampung Pelangi yaitu dengan mengubah image kawasan di Kota Tanjungpinang, terutama kawasan-kawasan yang mulanya memiliki kesan kumuh untuk direkayasa menjadi satu spot yang menarik dan layak dijadikan sebagai salah satu destinasi wisata baru pariwisata.

b. Fasilitator, sebagai fasilitator pemerintah daerah merujuk pada upaya Dinas dalam memfasilitasi masyarakat demi mewujudkan pariwisata berbasis masyarakat yang unggul dengan memfasilitasi berbagai macam kebutuhan masyarakat maupun wisatawan dalam menunjang kegiatan kepariwisataan. Upaya yang dilakukan Dinas Pariwisata dan Kebudayaan Kota Tanjungpinang dalam hal fasilitator dengan memfasilitasi masyarakat demi mewujudkan pariwisata berbasis masyarakat dan memfasilitasi berbagai macam kebutuhan masyarakat maupun wisatawan dalam menunjang kegiatan kepariwisataan. Adapun dalam menjalankan perannya sebagai fasilitator, Dinas Pariwisata dan Kebudayaan Kota Tanjungpinang bekerja sama dengan pihak swasta maupun masyarakat. 
c. Dinamisator, dalam keberlangsungan pembangunan yang ideal, maka pemerintah, swasta dan masyarakat harus dapat bersinergi dengan baik. Pemerintah daerah sebagai salah satu pemegang kekuasaan pembangunan pariwisata memiliki peran untuk mensinergiskan ketiga pihak tersebut, agar diantaranya tercipta suatu simbiosis mutualisme demi perkembangan pariwisata. Adapun bentuk bantuan dari hasil kerja sama yang dilakukan oleh Dinas Pariwisata dan Kebudayaan Kota Tanjungpinang dengan instansi pemerintahan, swasta maupun masyarakat, yaitu :

1. PT Angkasa Pura II (persero)berupa beberapa tempat sampah.

2. Bank Riaukepri berupa beberpa pot bunga dan tempat sampah.

3. Bank BCA berupa beberapa Kaleng cat.

4. Semangat Jaya Motor (SJM) berupa beberapa kaleng cat.

5. TIKI berupa beberpa kaleng cat.

6. JNE berupa beberapa kaleng cat.

\section{Peran Pemerintah Daerah dalam Membangun City Branding}

Dalam hal ini peneliti menggunakan pendekatan teori langkahlangkah membangun city branding menurut Saputra (2016:323) untuk menjawab penelitian yang peneliti lakukan, yaitu sebagai berikut:

a. Survei Pemetaan (Mapping Survey), merupakan kegiatan yang meliputi survey persepsi dan ekspektasi tentang suatu daerah dari masyarakat atau pihak-pihak luar yang terkait. Peran pemerintah daerah dalam proses pemetaan persepsi dan ekspektasi yang dilakukan oleh Dinas Pariwisata dan Kebudayaan Kota Tanjungpinang dalam membangun image city branding melalui wisata baru kampung pelangi yaitu dengan mengubah suatu kawasan yang mana sebelumnya tidak tertata, kumuh dan tidak dikenal menjadi kawasan yang menarik dan jadi lebih dikenal masyarakat dalam maupun luar daerah dengan menjadikannya sebuah merek atau branding kawasan wisata.

b. Analisis Kompetitif (Competitive Analysis), dimaksud untuk mengukur daya saing suatu daerah atau wisata dengan daerah lainnya pada level ekonomi makro dan mikro daerah itu sendiri. Sektor pariwisata merupakan sektor strategis karna dapat berkontribusi terhadap pertumbuhan ekonomi, menciptakan lapangan pekerjaan dan peningkatan pendapatan manyarakat. Adanya potensi yang dimiliki kampung pelangi, dengan tempatnya yang strategis dan dihuni oleh manyarakat melayu pesisir menjadi nilai keunikan tersendiri. Peran Dinas Pariwisata dan Kebudayaan Kota Tanjungpinang dimana mereka berusaha untuk mendorong mewujudkan perekonomian yang tangguh dan dapat meningkatkan perekonomian masyarakat dengan mengubah kampung yang awalnya kumuh untuk direkayasa menjadi 
satu spot yang menarik dan layak dijadikan sebagai salah satu destinasi wisata baru pariwisata.

c. Cetak Biru (Blueprint), merupakan penyusunan cetak biru daerah yang diinginkan, baik logo, semboyan, nama panggilan, tag line, beserta strategi branding dan strategi komunikasinya dalam mempromosikan suatu tempat wisata. Pemerintah daerah dalam hal ini Dinas Pariwisata dan Kebudayaan Kota Tanjungpinang melakukan perannya dalam pembuatan cetak biru atau blueprint dengan membuat tagline "Pesona Kampung Melayu Kampung Pelangi" dan dengan strategi pemasaran di media cetak dan media-media sosial.

d. Implementasi(Implementation), didalam membangun city branding menurut Saputa (2016:323) merupakan pelaksanaan grand design dalam berbagai bentuk media, seperti pembuatan media center, pembuatan events, iklan, dan lain sebagainya. Dalam implementasinya pemerintah daerah dalam hal ini Dinas Pariwisata dan Kebudayaan Kota Tanjungpinang berusaha untuk mendorong mewujudkan perekonomian yang tangguh dan dapat meningkatakan perekonomian masyarakat dengan salah satunya membangun wisata baru yaitu Kampung Pelangi. Pembangunan wisata kampung pelangi secara umum adalah untuk meningkatkan taraf hidup ekonomi masyarakat dan peningkatan pendapatan asli daerah. Namun demikian dalam implementasinya membangun city branding diharapkan pada semakin ketatnya persaingan antara daerah dalam menciptakan destinasi pariwisata yang mampu mendatangkan wisatawan dan investor.

\section{Penutup}

Berdasarkan hasil dan pembahasan yang telah disusun oleh peneliti, maka dapat disimpulkan bahwa: (1) Survei Pemetaan (Mapping Survey), peran pemerintah daerah dalam proses pemetaan persepsi dan ekspektasi yang dilakukan oleh Dinas Pariwisata dan Kebudayaan Kota Tanjungpinang dimana untuk membangun image city branding melalui kampung pelangi masih belum optimal dikarenakan masih kurangnya perencanaan dalam pengembangan kampung pelangi. (2) Analisis Kompetitif (Competitive Analysis), secara umum belum maksimal. Belum maksimalnya kompetensi dan SDM Dinas Pariwisata dan Kebudayaan Kota Tanjungpinang maupun masyarakat Kampung Pelangi dalam membangun city branding melalui kampung wisata baru ini masih sangat lemahnya dikarnakan kurangnya pengelolaan dan belum memadainya fasilitas-fasilitas pendukung. (3) Cetak Biru (Blueprint), peran pemerintah daerah dalam hal ini Dinas Pariwisata dan Kebudayaan Kota Tanjungpinang dalam cetak biru atau blueprint belum maksimal dikarnakan tidak adanya program pengembangan dan pengelolaan Kampung Pelangi. (4) Implementasi (Implementation), dikarnakan kurangnya perencanaan dan pengelolaan Dinas 
Pariwisata dan Kebudayaan Kota Tanjungpinang dalam membangun city branding melalui Kampung Pelangi membuat wisata kampung pelangi belum dapat direkomendasikan sebagai salah satu destinasi wisata yang harus dikunjungi di Kota Tanjungpinang.

Berdasarkan pembahasan dan kesimpulan yang diambil diatas, maka saran yang peneliti berikan dalam penelitian ini adalah: (1) Perlu diagendakan kegiatan rutin bersama masyarakat dan pelaku wisata di Kampung Pelangi agar tercipta hubungan yang harmonis dan kedekatan antara Pemerintah Daerah Khusunya Dinas Pariwisata dan Kebudayaan Kota Tanjungpinang dengan masyarakat di kampung pelangi tanpa menunggu momentum yang tepat. Misalnya, dengan membuat agenda rutin. (2) Perlu adanya kerjasama dinas pariwisata dan kebudayaan dengan pemerintah daerah lainnya, swasta serta masyarakat sekitar untuk mengadakan pelatihan atau peningkatan softskill kewirausahaan terhadap masyarakat sekitar objek wisata. (3) Sektor publik atau pemerintah harus bisa menyediakan infrastruktur dan kerangka regulasi yang dapat mendorong swasta dan masyarakat ikut berpartisipasi aktif dalam pembangunan kepariwisataan berbasis kampung wisata baru. Misalnya, dengan membuat kerangka kegiatan pengembangan yang akan dilakukan kedepannya. (4) Pemerintah daerah yang dalam hal ini bisa melalui Dinas Pariwisata dan Kebudayaan Kota Tanjungpinang harus lebih aktif berkontribusi dalam memberikan fasilitas kepada masyarakat setempat dan harus disertai dengan pendampingan langsung yang dilakukan secara berkala, selain untuk mengevaluasi apakah fasilitas yang diberikan telah tepat guna dan tepat sasaran dalam menghadapi berbagai kendala yang dihadapi.

\section{Daftar Pustaka}

Anholt, Simon.2007. Competitive Identity: The New Brand Management for Nations,

Citiesand Regions.USA:Palgrave Macmillan.

Apter, David E. 1977, Pengantar Analisa Politik, CV Rajawali, Jakarta

Creswel, J.W. 1998, Qualitative Inquiry and Reseach Design: Choosing among Five Tradition. London: Sage Publications.

Hankinson, G. 2001, "Location Branding: a Study of The Branding Practices of 12 English cities", Journal of Brand Management.

Pitana, I. Gede dan Gayatri, Putu G. 2015. Sosiologi Pariwisata. Yogyakarta.

Pemerintah Kota Makassar. 2014. Buku Saku City Branding Makassar. Makassar: Vier Antares Institute.

Poerwadarminta. 1995. Kamus Besar Bahasa Indonesia. Jakarta:Gramedia

Saputra, Eko 2016. "Peran dinas pariwisata ekonomi kreatif, komunikasi dan informatika dalam mengelola "branding" kota samarinda". Jurnal Komunikasi Fakultas Social Politik Universitas Mulawarman.

Spradley.P. James 1980. Participant Obsevation. Florida: Holt, Rinehart and Winston. 